DOI: https://doi.org/10.47405/mjssh.v5i8.464

\begin{tabular}{|c|c|}
\hline sist & Malaysian Journal of Social Sciences and Humanities (MJSSH) \\
\hline Malaysian Journal of & Volume 5, Issue 8, August 2020 \\
\hline (MJ-SSH) & e-ISSN : 2504-8562 \\
\hline & $\begin{array}{l}\text { Journal home page: } \\
\text { www.msocialsciences.com }\end{array}$ \\
\hline
\end{tabular}

\title{
A Study of Motives in Choosing Natural Cosmetics Among Indonesian Women
}

\author{
Sabila Anjani Syahrul ${ }^{1}$, Lidia Mayangsari1 \\ 1School of Business and Management, Bandung Institute of Technology, Indonesia
}

Correspondence: Sabila Anjani Syahrul (sabila_anjani@sbm-itb.ac.id)

\begin{abstract}
Due to its stable yet continuous growth, the beauty industry has intensely diversified both its marketing and managerial orientation toward consumer demands. The growth is in response to customer trends towards healthier lifestyles, where women aged within the range of 18 and 34 are concerned regarding the ingredients of the beauty products they purchase when it comes to selecting a specific cosmetic product. This study aims to measure the influence between consumption value (functional value, social value, conditional value, epistemic value, and emotional value) on motives in choosing natural cosmetics among 243 Indonesian Women specifically in Jabodetabek and Bandung. This research is conducted by questionnaire and analyzed using Confirmatory Factor Analysis in SmartPLS Software. The result of this research indicates that functional value, conditional value, epistemic value, and emotional value have positively influenced motives in choosing natural cosmetic products, where social value negatively influences motives in choosing natural cosmetics products. In applying the results of this research into marketing planning, natural cosmetics SMEs in Indonesia are advised to consider incorporating consumption values such as functional values, emotional values, conditional values, and epistemic values associated with the marketing of the product itself.
\end{abstract}

Keywords: choice behaviour, consumption values, natural, natural cosmetic products

\section{Introduction}

For the past 20 years the Global Beauty Market has shown an outstanding growth of $4.5 \%$ a year on average, with annual growth rates ranging from approximately $3 \%$ to $5.5 \%$. Meaning that this market has proven to be able to achieve a stable yet continuous growth as well as its ability for resilience in various disadvantageous economic conditions (Lopaciuk \& Loboda, 2013). Just like any other industries, in the last couple of years, the beauty industry has intensely diversified both its marketing and managerial orientation toward consumer demands. This is because of the growth in response to customer trends towards healthier lifestyles and requirements for products that possess natural aroma (Dimitrova, Kaneva and Gallucci, 2009). To overcome consumer demand as well as the regulators, various companies and producers are beginning to design, develop and sell natural cosmetics products. This is an effort solely with purpose to achieve a competitive advantage by standing out to grasp the market demand and attention (Green Choices, 2012; Zinkhan \& Carlson, 1995).

Apart from the promising record sales and growth in a Global Beauty Market, it has also affected the performance of the Indonesian Beauty Market. Indonesia itself will be one of the top five cosmetics markets for the next 10-15 years, this is due to its position as Southeast Asia's largest economy (Cheong et al., 2016). For domestic and international investors, the cosmetic industry in Indonesia 
remains an appealing industry as many Indonesians are becoming increasingly aware of their wellbeing. Nowadays, cosmetics are increasing to be a part of women's lifestyle, with support of a huge amount of the female population with over 130 million in Indonesia. At the moment, cosmetic products remain to be the main target of the cosmetics industry as it has become a primary requirement for women (The Insider Stories, 2020). In addition to that, a positive trend toward natural cosmetics can be seen as the green products companies are expanding at a rapid pace, meaning consumers also face an increasing concern to green companies in parallel (The Economist, 2012).

Consumers are shifting to natural as well as organic products as they prefer to avoid contentious synthetic chemicals in cosmetics (Premium Beauty News, 2018). Stated by Marinko (2017), women aged within the range of 18 and 34 are concerned regarding the ingredients of the beauty products they purchase when it comes to selecting a specific cosmetic product. Consumers spend more and more time to gain a deeper understanding about these products. Natural products are formulated from natural resources, meaning that it doesn't use colouring additives, chemicals, and other non-natural substances. While, for organic products, it does have a more strict definition where the product's ingredients must not contain toxic pesticides, chemicals, NPK fertilizers and all the claims are regulated based on USDA (Amberg \& Fogarassy, 2019). Moreover, women also want products that do not harm the environment. They prefer to understand the story of where the products' ingredients are from and whether the laborers are being fairly paid and no children exploitation during the process of sourcing ingredients (Alabi, 2018).

As the natural products demand continues to expand in conventional channels, the multinationals cannot ignore this important trend (Alabi, 2018). Giant cosmetics makers are trying to jump on the natural cosmetics bandwagon launching their natural ranges. Unilever Indonesia is an example of a multinational company that creates a new brand that supports environmental sustainability issues and is made from natural ingredients. Sensatia Botanical, a local made skincare company built in 2000 in Karangasem on the east coast of Bali, has made an impressive run in the cosmetic industry. Sensatia Botanical successfully became a trademark in more than 40 countries, with more than 200 products registered with the Food and Drug Administration (BPOM). According to Damayanti (2017), what makes their products desired by customers is that they are made from $100 \%$ natural high quality ingredients, even a pregnant woman safe to use the products. In every packaging, they provide steps to use the products which make customers understand easily and perfectly wrapped in natural colors. Sensatia Botanical has become the first local beauty brand to have a packaging recycling program that is more suitable for the environment.

Understanding the example of Sensatia Botanical, it can be concluded that there are various motives for consuming natural cosmetics. Sheth, Newman \& Gross (1991) stated that there are 5 values who influence consumer choices and were constructed as a theory of consumption. Those values can be classified into five values which are functional value, social value, emotional value, conditional value, and epistemic value. Each of the values has a different conduct for choosing a product. The theory of consumption can be used to define the reason why customers choose to buy or use, choose one product type, and choose one brand of a specific product over another (Sheth et al., 2019).

According to Kushwah, Dhir, Sagar \& Gupta (2019) a systematic literature review that consisted of a total of 89 empirical studies concluded that the motives of organic food consumption found out that from those five consumption values, only three values play a role as the critical motivator of organic food consumption which are functional value, social value, and conditional value. The result of this research is expected to be able to help local SMEs to measure motives in choosing natural cosmetics in order to improve the business strategies based on consumer's specific needs and requirements.

\section{Literature Review}

\section{Consumer Behaviour in Natural Cosmetics}


In the past, cosmetic producers used chemical substances to substitute the usage of natural ingredients which cost higher so it can be universally used by consumers. Today, the healthier way of living trends do affect the rising consumer's interest and perception in relation to products that are containing natural substances, including cosmetic products (Matic \& Puh, 2016). The rebirth of natural cosmetics is formed by the changing of consumers' by becoming more sustainable and healthy in their lifestyles. According to Zablocki and Kanter (1976), lifestyle is defined as "consumption's pattern which reflects a consumer's choices on the way they use their money and time, those choices portrayal in describing consumers identity". The lifestyle changes are emerging because consumers are becoming more aware of the unethical consequences of their everyday lifestyle choices (Kilbourne McDonagh \& Prothero, 1997).

Hassan (2018) stated that in assessing how consumers generate decisions on their purchase behaviour, we could use consumer decision-making as a physiological and cognitive approach. By using decision making, consumers can determine which products they wanted to buy from the varieties of the product available and decide whether to repurchase or not (Mokhlis \& Salleh, 2009).

\section{Motives on Choosing Natural Cosmetics}

To understand consumer choice behaviour, it is important to recognize how consumers make decisions and the criteria are used in choosing the selected product over another. Sheth et al., (1991) stated that there are 5 values who influence consumer choices and were constructed as a theory of consumption. These values include functional value, social value, emotional value, epistemic value, and conditional value. Each of these values has a different performance while choosing a product. The theory of consumption defines the reason why customers choose to buy or use, choose one product type, and choose one brand of a specific product over another. In the business terms as a buying decision, motive can be explained as the driving force within individuals that drives them to buy products. For better understanding of customer's motives in choosing natural cosmetic, it can be explored by analysing theory of consumption as mentioned above:

\section{Functional Value}

Functional value can be specified as a group of motives that are related to the product-centric attributes, how functional features influence the perceived benefit for the user of the underlying product (Sheth et al., 1991). A study conducted by Rahnama (2017) concluded that quality and price of a product does significantly influence women's choice in consuming organic food products. Moreover, he stated that functional value infer to be the fundamental driver of consumer in choosing a product.

\section{Social Value}

Social value is characterized as the product's perceived capacity to give the consumer the desired social status (Sheth et al., 1991). Social value is related to symbolic meaning, in which it is often correlated with the social image of the consumers and the other motives besides the function of the product (Yoo, Divita \& Kim, 2013). In the study about organic products, Shin, Im, Jung, \& Severt (2018) used social norms and social status as the attributes to assess the social value. They found out that customers who feel like to enhance their social status or acceptance often choose to go to restaurants who offer organic foods. In addition, consumers also don't mind paying premium prices.

\section{Conditional Value}

Conditional value relates to the option of the product due to the situation and circumstances faced by someone who makes the choices, which are the consumers (Sheth et al., 1991). Situations corresponded with place, time and context have a significant influence on the consumer's choice behavior based on the type of the product (Belk, 1974; Lin \& Huang, 2012). When personal situations change then consumer purchases are affected (Laaksonen, 1993). 


\section{Epistemic Value}

According to (Sheth et al., 1991), epistemic value debates that it is 'the perceived utility to trigger curiosity, giving novelty or answer a longing for knowledge'. Laroche et al. (2001) stated that the knowledge that customers have is one of the characteristics which influences the whole phase of the decision process. When it comes to the purchase situation, the knowledge related to the product takes a big part in identifying the new product adoption. When customers find a new product and consider purchasing it, they figure it out by looking at the product they have known and the information related to those new products (Lai, 1991).

\section{Emotional Value}

Emotional value discusses the perceived benefit captured to stimulate feelings when consumers positively experience a certain product or services (Sheth et al., 1991). Holbrook (1986) initiates to consider consumption experience as a scheme where emotions, values and consciousness are involved. Each one of the customers might have different emotional values, which may influence their purchase decision, based on their type of personal and emotional experience.

\section{Conceptual Framework and Hypotheses}

This research is using the innovation resistance theory as the framework model, developed by Rahnama (2017), shown in Figure 1. The relationships between the variables are as follows: Emotional value, social value, conditional value, social value, epistemic value, and emotional can affect the motives on choosing natural cosmetic products.

Figure 1: Conceptual Framework

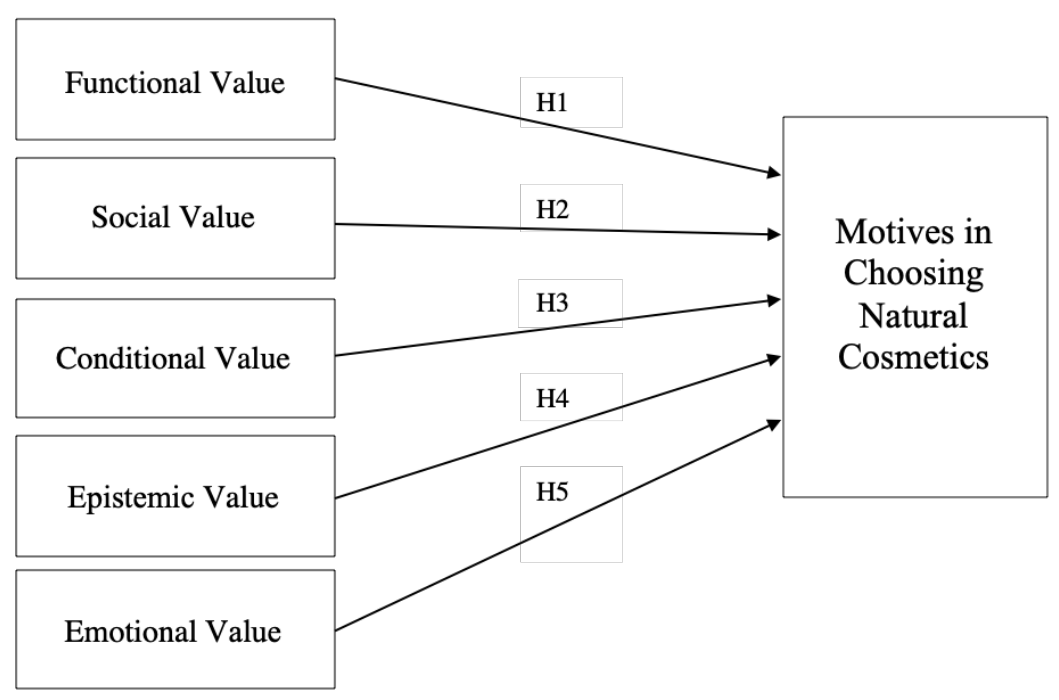

Based on the literature review and conceptual framework, the hypotheses are:

H1: Functional value does have a positive influence towards motives of choosing natural cosmetics

H2: Social value does have a positive influence towards motives of choosing natural cosmetics

H3: Conditional value does have a positive influence towards motives of choosing natural cosmetics

H4: Epistemic value does have a positive influence towards motives of choosing natural cosmetics 
Malaysian Journal of Social Sciences and Humanities (MJSSH), Volume 5, Issue 8, (page 60 - 71), 2020

DOI: https://doi.org/10.47405/mjssh.v5i8.464

H5: Emotional value does have a positive influence towards motives of choosing natural cosmetics

\section{Methodology}

\section{Research Design}

The data collection is using quantitative methods and will be analysed using modelling of the structural equation. The data collection using a survey will be conducted using an online questionnaire in order to assess the motives of Indonesian women in choosing natural cosmetics.

\section{Population}

The target population for this study are women who live in Jabodetabek and Bandung ranging from 1834 years old who have been using or purchasing natural cosmetic products.

\section{Sampling Procedures}

The chosen technique for this study is non-probability sampling. Battaglia (2011) stated that a method that applied non-randomized methods to draw a sample known as non-probability sampling. Since the constructed sample does count as the representative from the population, the purposive sampling as part of non-probability sampling is used for this study (Battaglia, 2011).

Malhotra \& Birks (2005) stated in their book titled Marketing Research: An Applied Approach, sample size is a number of elements that participated in the study. It is stated that the minimum amount of samples are 200-400 respondents. To conclude, the amount of sample size for this study is 423 women ranging from 18-34 years old.

\section{Data Collection}

The questionnaire that is given to the respondents consists of 2 parts. The first one is sociodemographic data regarding the respondent's gender, age, current domicile, and occupation. The next part is intended to assess the independent variables which are functional value, social value, conditional value, epistemic value, and emotional value. All the questions were written in Bahasa Indonesia and measured with a 5-point Likert scale ranging from 1 (strongly disagree) to 5 (strongly agree).

Online questionnaire in Bahasa Indonesia is used to collect the data from respondents since the limitation area is in Jabodetabek and Bandung. Moreover, Google form is used to create the online questionnaire. Before beginning to distribute the questionnaire, the researcher conducted a pilot test and carried out validity and reliability tests before collecting the data.

Table 1: Distribution of Respondent Demographics

\begin{tabular}{lll}
\hline Variable & Category & Frequency (\%) \\
Gender & Female & $243(100 \%)$ \\
Domicile & Jabodetabek & $175(28 \%)$ \\
& Bandung & $68(72 \%)$ \\
& Senior High School & $115(47.3 \%)$ \\
Level of Education & Diploma & $10(4.1 \%)$ \\
& Bachelor Degree & $116(47.7 \%)$ \\
\hline
\end{tabular}




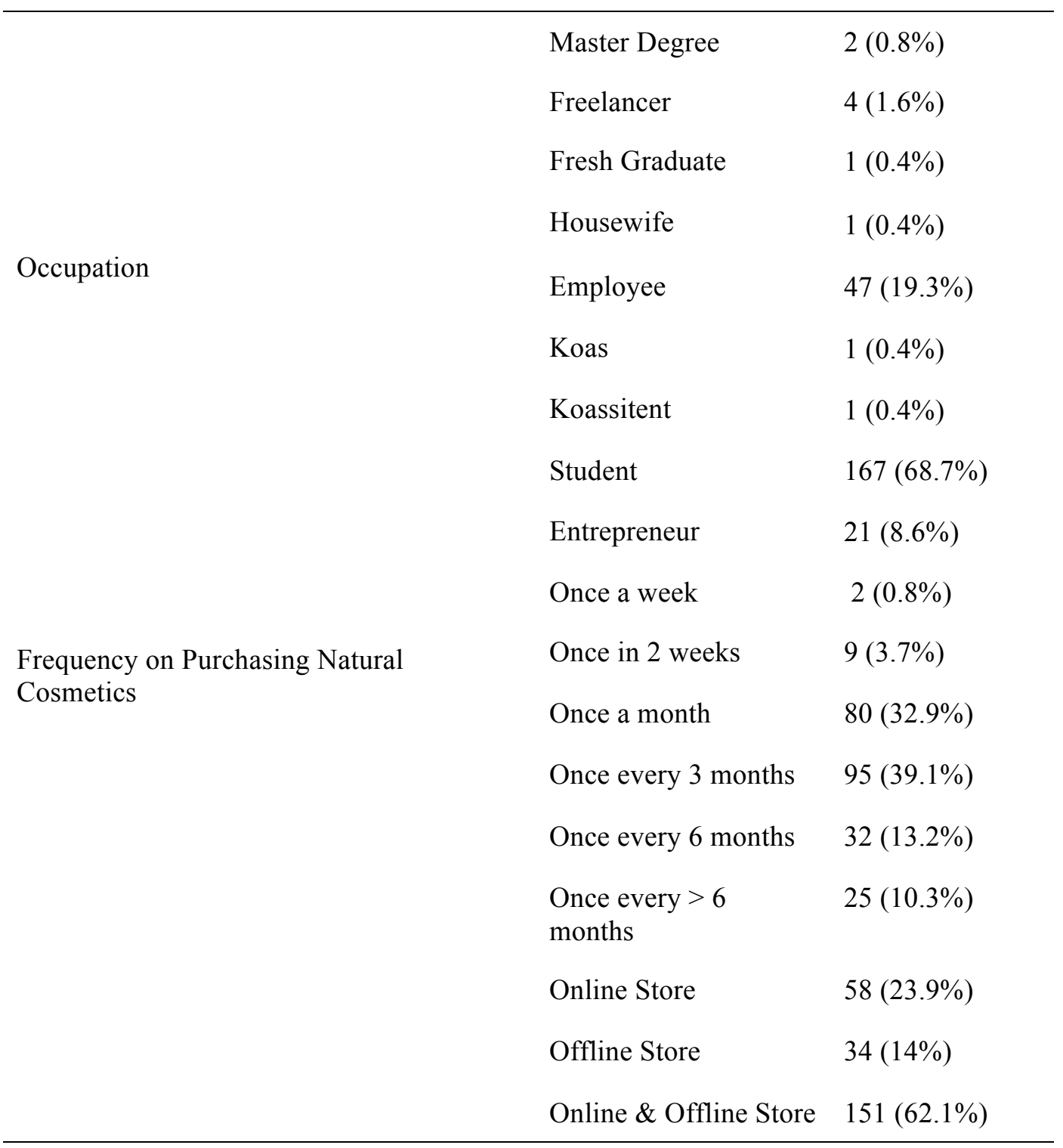

Functional value are measured using four items representing price and quality by Rahnama (2017), Lin and Huang (2012), Sheth et al. (1991). Social value are measures using four items representing social norms and social status by Rahnama (2017), Lin and Huang (2012), Sheth et al. (1991). Conditional value are measured using four items representing context and time and place by Rahnama (2017), Lin and Huang (2012), Sheth et al. (1991). Epistemic values are measured using four items representing novelty and knowledge by Rahnama (2017), Lin and Huang (2012), Sheth et al. (1991), Biswas and Roy (2015). Emotional values are measured using two items representing the profile of feeling by Rahnama (2017), Lin and Huang (2012), Sheth et al. (1991). Lastly, motives in choosing natural cosmetics are measure with two items representing willingness to choose by Choi and Kim (2005), Lin and Huang (2012).

\section{Data Analysis}

Confirmatory factor analysis (CFA) is a multivariate analysis method which is known to confirm whether the measurement model that was built in conformance with what was hypothesized (Hair et al., 2009). In this research, the confirmatory factor analysis is used to prove whether functional value, emotional value, conditional value, epistemic value and emotional value are the indicators of motives on choosing natural cosmetics among Indonesian women. The data for this research is processed using SmartPLS 3.0, by doing PLS algorithm and bootstrapping.

\section{Results}




\section{Convergent Validity}

Convergent validity is used to determine the instrument items that can be used as indicators of overall latent variables. The results of this test are measured based on the value of the factor loading (outer loading) of the construct indicator. Convergent Validity will be fulfilled if the Factor Loading value of each indicator is $>0.7$. Factor Loading, Composite Reliability, and Average Variance Extracted is used to test convergent validity (Hair et al., 2009).

\section{a) Factor Loading}

Convergent validity is satisfied if the load factor value for each item is $>0.5$, and if $>0,7$ it shown ideal value (Hair et al., 2009).

Based on Table 2 it is known that all indicators have a factor loading value $>0.5$. This shows that all indicators in this study meet convergent validity and can be continued in further testing.

Table 2: Factor Loading

\begin{tabular}{|c|c|c|c|}
\hline Construct & Code & Item & $\begin{array}{l}\text { Factor } \\
\text { Loading }\end{array}$ \\
\hline \multirow{4}{*}{ Functional Value } & FV1 & Natural cosmetic has consistent quality & 0.8170 \\
\hline & FV2 & $\begin{array}{l}\text { Natural cosmetic has an acceptable } \\
\text { standard of quality }\end{array}$ & 0.8373 \\
\hline & FV3 & Natural cosmetics are reasonably priced. & 0.7917 \\
\hline & FV4 & $\begin{array}{l}\text { Natural cosmetic product offers value } \\
\text { for money }\end{array}$ & 0.8394 \\
\hline \multirow{4}{*}{ Social Value } & SV1 & $\begin{array}{l}\text { Buying natural cosmetics would help me } \\
\text { to feel acceptable }\end{array}$ & 0.8545 \\
\hline & SV2 & $\begin{array}{l}\text { Buying natural cosmetic would improve } \\
\text { the way that I am perceived }\end{array}$ & 0.8599 \\
\hline & SV3 & $\begin{array}{l}\text { Buying natural cosmetic would make a } \\
\text { good impression on other people }\end{array}$ & 0.7583 \\
\hline & SV4 & $\begin{array}{l}\text { Buying natural cosmetic would give its } \\
\text { owner social approval }\end{array}$ & 0.7586 \\
\hline \multirow{4}{*}{ Conditional Value } & CV1 & $\begin{array}{l}\text { I would buy the natural cosmetic } \\
\text { products instead of conventional } \\
\text { cosmetic products under worsening } \\
\text { environmental conditions. }\end{array}$ & 0.8473 \\
\hline & $\mathrm{CV} 2$ & $\begin{array}{l}\text { I would buy the natural cosmetic } \\
\text { products instead of conventional } \\
\text { cosmetic products under worsening } \\
\text { physical conditions. }\end{array}$ & 0.7777 \\
\hline & CV3 & $\begin{array}{l}\text { I would buy the natural cosmetic } \\
\text { products instead of conventional } \\
\text { products when natural cosmetic are } \\
\text { available }\end{array}$ & 0.8473 \\
\hline & CV4 & $\begin{array}{l}\text { I would buy the natural cosmetic } \\
\text { products instead of conventional } \\
\text { cosmetic products when there are } \\
\text { discount rates for natural cosmetic or } \\
\text { promotional activity }\end{array}$ & 0.9407 \\
\hline
\end{tabular}


Malaysian Journal of Social Sciences and Humanities (MJSSH), Volume 5, Issue 8, (page 60 - 71), 2020

DOI: https://doi.org/10.47405/mjssh.v5i8.464

\begin{tabular}{|c|c|c|c|}
\hline \multirow{4}{*}{ Epistemic Value } & EPIS1 & $\begin{array}{l}\text { Before buying the product, I would } \\
\text { obtain substantial information about the } \\
\text { different makes and models of products }\end{array}$ & 0.7709 \\
\hline & EPIS2 & $\begin{array}{l}\text { I would acquire a great deal of } \\
\text { information about the different makes } \\
\text { and models before buying the product }\end{array}$ & 0.8115 \\
\hline & EPIS3 & $\begin{array}{l}\text { I am willing to seek out novel } \\
\text { information }\end{array}$ & 0.7827 \\
\hline & EPIS4 & I like to search for the new and different & 0.8256 \\
\hline \multirow{2}{*}{ Emotional Value } & EMOV1 & $\begin{array}{l}\text { Buying the green product instead of } \\
\text { conventional cosmetic products would } \\
\text { feel like the morally right thing }\end{array}$ & 0.9238 \\
\hline & EMOV2 & $\begin{array}{l}\text { Buying the green product instead of } \\
\text { conventional cosmetic products would } \\
\text { make me feel like a better person. }\end{array}$ & 0.9327 \\
\hline \multirow{2}{*}{$\begin{array}{l}\text { Motives of } \\
\text { Choosing Natural } \\
\text { Cosmetics }\end{array}$} & CB1 & $\begin{array}{l}\text { I make a special effort to buy natural } \\
\text { cosmetics products }\end{array}$ & 0.9053 \\
\hline & $\mathrm{CB} 2$ & $\begin{array}{l}\text { When I have a choice between two equal } \\
\text { cosmetics products, I purchase the } \\
\text { natural one }\end{array}$ & 0.8817 \\
\hline
\end{tabular}

\section{b) Construct Reliability and Validity}

To determine the reliability of each of the constructs of this study, a test was performed by looking at the value of Composite Reliability and Cronbach's Alpha of each construct. To be able to meet good reliability, the composite reliability value must be greater than 0.7 , the Cronbach alpha value must be greater than 0.6, and the AVE value must be or greater than 0.5 (Wong, 2013). The following composite reliability results in Table 3 :

Table 3: Construct Reliability and Validity

\begin{tabular}{lccc}
\hline \multicolumn{1}{c}{ Variable } & $\begin{array}{c}\text { Composite } \\
\text { Reliability }\end{array}$ & Cronbach's Alpha & AVE \\
\hline Functional Value & 0.892 & 0.840 & 0.675 \\
Social Value & 0.883 & 0.823 & 0.655 \\
Conditional Value & 0.916 & 0.876 & 0.731 \\
Epistemic Value & 0.875 & 0.812 & 0.637 \\
Emotional Value & 0.926 & 0.840 & 0.862 \\
Motives of Choosing & 0.888 & 0.748 & 0.799 \\
Natural Cosmetics & & & \\
\hline
\end{tabular}

Based on Table 3 it can be explained that the results of the composite reliability test show good results because the latent variables are all reliable because they have a composite reliability value greater than 0.7. This shows that all indicators are measuring their respective constructs. Then from Table 3 it can be seen that all latent variables have a Cronbach's alpha value above 0.7. Likewise with the AVE value in the study variable has a value above 0.5 . So it can be concluded that this study has met the reliability. 


\section{Discriminant Validity}

Discriminant Validity is done to show that all constructs are different from one another. Fornell \& Larcker (1981) states that discriminant validity is evaluated by correlation between constructs. The square root of the AVE value of each construct must be higher than all construct's correlation values.

Table 4: Discriminant Validity Fornell-Larcker

\begin{tabular}{llllllll}
\hline & & CV & & EMOV & EPIS & FV & \multicolumn{1}{c}{ SV } \\
\hline CB & $\mathbf{0 . 8 9 4}$ & & & & & & \\
CV & 0.641 & $\mathbf{0 . 8 5 5}$ & & & & & \\
EMOV & 0.644 & 0.559 & $\mathbf{0 . 9 2 8}$ & & & \\
EPIS & 0.459 & 0.341 & 0.433 & $\mathbf{0 . 7 9 8}$ & & \\
FV & 0.512 & 0.488 & 0.453 & 0.409 & $\mathbf{0 . 8 2 2}$ & \\
SV & 0.479 & 0.453 & 0.576 & 0.304 & 0.306 & $\mathbf{0 . 8 0 9}$ \\
\hline
\end{tabular}

Table 4 shows that all constructs are different from each other. Diagonal shows the square root of the AVE value of each construct and the construct correlation value is higher than the other correlation values among constructs. It means that each construct is different from one another.

\section{Hypotheses Testing and Discussion}

The table 5 shows the significant level of each construct towards the dependent variable. The result showed that $\mathrm{H} 1, \mathrm{H} 3, \mathrm{H} 4$, and $\mathrm{H} 5$ has t-value above 1.96 and p-value less than 0.5 . It can be said that functional value (FV), conditional value (CV), epistemic value (EPIS), and emotional value (EMOV) have significantly influenced the motives of choosing natural cosmetic products. Meanwhile, $\mathrm{H} 2 \mathrm{has}$ a t-value below 1.96, meaning that it is rejected. It means social value (SV) does not significantly influence the motives of choosing natural cosmetic products.

Table 5: Hypothesis Testing Result

\begin{tabular}{llll}
\hline Hypothesis & $\begin{array}{l}\text { T Statistics } \\
(|\mathbf{O} / \mathbf{S T D E}|)\end{array}$ & P Values & Decision \\
\hline $\begin{array}{l}\text { H1: Functional value does have a positive influence } \\
\text { towards motives of choosing natural cosmetics }\end{array}$ & 2.433 & 0.015 & Accepted \\
$\begin{array}{l}\text { H2: Social value does have a positive influence } \\
\text { towards motives of choosing natural cosmetics }\end{array}$ & 1.512 & 0.131 & Rejected \\
$\begin{array}{l}\text { H3: Conditional value does have a positive influence } \\
\text { towards motives of choosing natural cosmetics }\end{array}$ & 4.551 & 0.000 & Accepted \\
$\begin{array}{l}\text { H4: Epistemic value does have a positive influence } \\
\text { towards motives of choosing natural cosmetics }\end{array}$ & 2.350 & 0.019 & Accepted \\
$\begin{array}{l}\text { H5: Emotional value does have a positive influence } \\
\text { towards motives of choosing natural cosmetics }\end{array}$ & 4.156 & 0.000 & Accepted \\
\hline
\end{tabular}

This research is conducted to measure the influence of functional value, social value, conditional value, epistemic value, and emotional value towards motives of choosing natural cosmetic products among Indonesian women aged 18-34 years old. By using confirmatory factor analysis (CFA), we can determine the relationship between each construct. From H1, functional value does have a positive influence towards motives of choosing natural cosmetics. A study conducted by Rahnama (2017) 
concluded that quality and price of a product does significantly influence women's choice in consuming organic food products. Consumers do realize that paying a higher price for organic products is worthwhile so that it's not a problem to spend a bigger amount of money. It has p-value 0.015 and tvalue 2.433 where $\mathrm{H} 0$ is rejected and $\mathrm{Ha}$ is accepted. It can be concluded that functional value has a positive influence on the motives of choosing natural cosmetics.

For H2, social value does have a positive influence towards motives of choosing natural cosmetics. It has p-value 0.131 and t-value 1.512 where $\mathrm{H} 0$ is accepted and $\mathrm{Ha}$ is rejected. It means that social value (social norms and status) doesn't have a positive influence on the respondent on choice behaviour towards natural cosmetic products. The results of the hypothesis against the results of previous studies conducted by Costa et al. (2014) and Shin et al. (2018) where consumers choose organic products to enhance their social status and acceptance among their society. It can be concluded that social value including social norms and social status do not significantly influence respondents in choosing natural cosmetic products.

H3 expressed that conditional value does have a positive influence towards motives of choosing natural cosmetics. It has p-value 0.000 and t-value 4.551 where $\mathrm{H} 0$ is rejected and $\mathrm{Ha}$ is accepted. It means that conditional value positively influenced respondents in choosing natural cosmetics. In this research, context, time, and place are assessed whether it influences respondents in choosing natural cosmetics. The results of the hypothesis support the results of previous study conducted by Lin \& Huang (2012) where conditional values influence consumer behaviour in choosing green products in Taiwan and consumers record environmental consequences during the decision making process. It can be concluded that conditional value connected with environmental context, physical context, time, and place has a positive influence on the motives of choosing natural cosmetics.

The next is H4, where epistemic value does have a positive influence towards motives of choosing natural cosmetics. It has p-value 0.019 and t-value 2.350 where $\mathrm{H} 0$ is rejected and $\mathrm{Ha}$ is accepted. The indicator of epistemic value is novelty and desirability of knowledge regarding the products, in the sense that consumers with product awareness are more concerned with the appearance of natural cosmetics product design and style and are more likely to try something different. The results of the hypothesis support the results of previous studies conducted by Rahnama (2017) and Biswas \& Roy (2015) where consumers' knowledge related to the product is one of the main factors that influence them in consuming organic food products. To conclude, epistemic value positively influences respondents in choosing natural cosmetics.

Lastly, H5, emotional value does have a positive influence towards motives of choosing natural cosmetics. It has p-value 0.000 and t-value 4.156 where $\mathrm{H} 0$ is rejected and $\mathrm{Ha}$ is accepted. It means that emotional value positively influenced respondents in choosing natural cosmetics. By choosing natural cosmetics, the respondents feel that it is morally right and they become a better person. The results of the hypothesis support the results of previous studies conducted by Lin and Huang (2012) where emotional value has a significant impact for the consumer on selecting green products. To conclude, emotional value positively influences respondents in choosing natural cosmetics.

\section{Conclusion and Recommendations}

Regarding the choice behaviour, by using confirmatory factor analysis (CFA) method, the researchers found that out of five consumption values (functional value, social value, conditional value, epistemic value and emotional value), four of them significantly impact the motives in choosing natural cosmetics. It was founded that functional value, conditional value, epistemic value, and emotional value positively influence the motives in choosing natural cosmetics. Whereas, the social values do not positively influence the motives in choosing natural cosmetics.

Based on the result above, there are recommendations for natural cosmetics SMEs. The company must pay attention to consumers who buy natural cosmetics at a higher price than conventional products, it must be in accordance with the quality obtained and the benefits from using natural products. Messages 
related to green marketing that are targeted to consumers preferably using emotional elements that are in the form of invitations about environmental care. By using sentences that contain positive ideas such as "say no to plastic" or "natural is eternal" should be included in the messages that will be conveyed in a natural product campaign. Two aspects that are correlated with conditional value are global warming and threats to the environment. The phenomenon of weather changes and how they contribute to environmental disadvantage needed to be emphasized by the marketers in order to stimulate the customer to shift from conventional to natural cosmetic products.

This study has limitations from the demographic aspect since the researchers limited the studies to Indonesian women specifically who were living in Jabodetabek and Bandung aged 18 to 34 years old. This study focuses on the consumption values and choice behaviour variables, whereas the industry is limited on natural cosmetic products. Sampling method and online questionnaire via google form is the chosen technique to obtain the data. The result from this study could not reverse the whole Indonesian society. For further research, the researcher can consider broadening the research area to other cities with larger sample sizes. Moreover, the researcher can add other variables such as environmental concern variables that can influence choice behaviour of customers.

\section{References}

Alabi, F. (2018). What Women Really Want from Their Beauty Products. [online] Beauty Packaging. Available At: <https://www.beautypackaging.com/contents/view_experts-Opinion/2018-0517/what-Women-Really-Want-From-Their-Beauty-Products/> [accessed 2 May 2020].

Amberg, N. \& Fogarassy, C. (2019). Green Consumer Behavior in the Cosmetics Market. Resources, 8(3), 37.

Battaglia, M. (2011). Encyclopedia of Survey Research Methods: Nonprobability Sampling. Thousand Oaks: Sage Publications, Inc.

Belk, R. (1974). Situational Variables and Consumer Behavior. Journal of Consumer Research, 2(3).

Cheong, H., Lindsten, T. \& Thompson, C. (2016). Autophagy and ammonia. Autophagy, 8(1), 122123.

Damayanthi, A. (2017). Skin Care Review: Sensatia Botanicals Voyage of a Big Girl. [online] Ayudamayanthi.com. Available At: <http://www.ayudamayanthi.com/2017/01/beauty-ReviewSensatia-Botanicals.html $>$ [accessed 2 May 2020].

Dimitrova, V., Kaneva, M. \& Gallucci, T. (2009). Customer Knowledge Management in the Natural Cosmetics Industry. Industrial Management \& Data Systems, 109(9), 1155-1165.

Fornell, C. \& Larcker, D. F. (1981). Structural Equation Models With Unobservable Variables

Green Choices. (2012). Toiletries \& Cosmetics Green Choices. [online] Available At: $<$ https://www.greenchoices.org/green-Living/toiletries-Cosmetics/what-You-Can-Do> [accessed 2 May 2020].

Hair, J.f. \& Black, W. C. (2009). Multivariate Data Analysis. 7th International Economy And Measurement Error: Algebra and Statistics

Hassan, R. (2018). Impact of Viral Marketing Messages on Consumer Purchase Intention.

Holbrook, M. (1986). "emotion in the Consumption Experience: Toward a New Model of the Human Consumer" in the Role of Affect in Consumer Behavior: Emerging Theories and Applications,. Pp.17-52.

Kilbourne, W., Mcdonagh, P. \& Prothero, A. (1997). Sustainable Consumption and the Quality of Life: a Macromarketing Challenge to the Dominant Social Paradigm. Journal of Macromarketing, 17(1), 4-24.

Kushwah, S., Dhir, A., Sagar, M. \& Gupta, B. (2019). Determinants of Organic Food Consumption. a Systematic Literature Review on Motives and Barriers. Appetite, 143, 104402.

Laaksonen, M. (1993). Retail Patronage Dynamics: Learning About Daily Shopping Behavior in Contexts of Changing Retail Structures. Journal of Business Research, 28(1-2), 3-174.

Lai, A. (1991). Consumption Situation and Product Knowledge in the Adoption of a New Product. European Journal of Marketing, 25(10), 55-67.

Łopaciuk, A. \& Łoboda, M. (2013). Global Beauty Industry Trends in the 21 st Century. Management, Knowledge and Learning,. 
Malhotra, N. \& Birks, M. (2005). Marketing Research: an Applied Approach. Pearson Education Limited.

Martinko, K. (2017). More Women Are Buying Green Beauty Products. [online] Treehugger. Available At: <https://www.treehugger.com/organic-Beauty/more-Women-Are-Buying-GreenBeauty-Pro Ducts.html> [accessed 2 May 2020].

Matić, M. \& Puh, B. (2016). Consumers' Purchase Intentions Towards Natural Cosmetics. Ekonomski Vjesnik/econviews-Review of Contemporary Business, Entrepreneurship and Economic Issues, 29(1), 53-64.

Mokhlis, S. and Salleh, H., 2009. Decision-Making Styles of Young Malay, Chinese and Indian Consumers in Malaysia. Asian Social Science, 5(12).

Premium Beauty News. (2018). Multinationals Jump on Natural Cosmetics Bandwagon. [online] Available At: $\quad<$ https://www.premiumbeautynews.com/en/multinationals-Jump-OnNatural,14231> [accessed 2 May 2020].

Rahnama, H. (2017). Effect of Consumption Values on Women's Choice Behavior Toward Organic Foods: the Case of Organic Yogurt in Iran. Journal of Food Products Marketing, 23(2), 144166.

Sensatia.com. (2020). Welcome To Sensatia Botanicals - Bali'S Best Natural Skin Care

[online] Available at: $<$ https://sensatia.com/> [Accessed 27 July 2020].

Sheth, J., Newman, B. \& Gross, B. (1991). Why We Buy What We Buy: a Theory of Consumption Values. Journal of Business Research, 22(2), 159-170.

Shin, Y., Im, J., Jung, S. \& Severt, K. (2018). Motivations Behind Consumers' Organic Menu Choices: the Role of Environmental Concern, Social Value, and Health Consciousness. Journal of Quality Assurance in Hospitality \& Tourism, 20(1), 107-122.

The Economist. (2012). Busted Trust. [online] Available At: $<$ https://www.economist.com/newsbook/2012/01/23/busted-Trust $>$ [accessed 2 May 2020].

The Insider Stories. (2020). Indonesia's Shimmering Cosmetics Industry. [online] Available At: $<$ https://theinsiderstories.com/indonesias-Shimmering-Cosmetics-Industry/> [accessed 2 May 2020]. Using Smartpls. Marketing Bulletin, 24(1), Pp.1-32.

Wong, K. K. K. (2013). Partial Least Squares Structural Equation Modeling (pls-Sem) Techniques

Yoo, J., Divita, L. \& Kim, H. (2013). Environmental Awareness on Bamboo Product Purchase Intentions: Do Consumption Values Impact Green Consumption?. International Journal of Fashion Design, Technology and Education, 6(1), 27-34.

Zablocki, B. \& Kanter, R. (197. The Differentiation of Life-Styles. Annual Review of Sociology, 2(1), 269-298.

Zinkhan, G. \& Carlson, L. (1995). Green Advertising and the Reluctant Consumer. Journal of Advertising, 24(2), 1-6. 